Acta Technologica Agriculturae 1

Nitra, Slovaca Universitas Agriculturae Nitriae, 2017, pp. 1-6

\title{
EFFECT OF CLIMATIC CONDITIONS ON DIFFERENCES IN THERMO-TECHNICAL PROPERTIES OF ORGANIC BEDDING IN LABORATORY TESTING
}

\author{
Jana LENDELOVÁ*, Ingrid KARANDUŠOVSKÁ, Miroslav ŽITŇÁK, Štefan BOĎO, Štefan MIHINA \\ Slovak University of Agriculture in Nitra, Slovak Republic
}

\begin{abstract}
The aim of this experiment was to analyse the influence of climatic factors on the thermal performance of separated liquid manure. The samples of organic bedding were collected from the lying area of dairy housing and preparatory store. The measurement of properties of recycled manure solids (RMS) was carried out in laboratory conditions. Samples were examined with determining the temperature effect on the thermal conductivity $\lambda$ of 'dry' separated liquid manure (with a dry matter content of $60 \%$ ) and 'wet' liquid manure (with a dry matter content of $26 \%$ ), in air temperatures ranging from $0{ }^{\circ} \mathrm{C}$ to $40^{\circ} \mathrm{C}$. Subsequently, the thermal resistance of three selected types of cows lying structures was calculated for winter and summer boundary values. Based on the results of thermal conductivity and thermal resistance, it was observed that dry separated liquid manure as an alternative bedding has, in low temperature (up to $5^{\circ} \mathrm{C}$ ), the most suitable thermal performance if it is maintained in a dry condition (with a dry matter content of $60 \%$ ). With increasing temperature (above $20^{\circ} \mathrm{C}$ ) and increasing humidity of bedding (below $26 \%$ ), thermo-technical properties get worse; however, when comparing the thermal resistance of the cow bed structure with sandwich mattresses with a $50 \mathrm{~mm}$ layer of organic bedding and the deep cubicle filled with $200 \mathrm{~mm}$ of organic bedding, the thermal resistance of floor structure decreases by $7.6 \%$ or $18.4 \%$, respectively. With a proper handling of the recycled organic bedding, it is possible to use its economic advantages.
\end{abstract}

Keywords: cow; recycled manure solids; thermal conductivity

A great attention to the application of liquid manure is currently being paid in livestock production, so as to be used not only as a source of nitrates for fertilisation, but also in other agricultural activities (Jelínek et al., 2006). Bedding housing systems are prevalent in livestock in Slovakia. Loose housing uses bedding cubicles or pens with a bedding layer (Brestenský and Botto, 2010). Bedding material is a very costly part of dairy farming and has a significant impact both on animal health and on the environment (Herbut and Angrecka, 2014).

It is an increasingly difficult problem to ensure a reliable source of bedding for farmers. Dairy farms are therefore constantly under increasing pressure to improve their manure management. The separated slurry of manure, also called as 'green litter', is used for bedding in the areas where the availability of standard bedding material is decreasing. It is a separated raw liquid manure or separated digested sludge from a biogas plant (Lendelová et al., 2015). Farmers using this material report greater cow comfort than with other bedding materials they have used and the potential financial savings are substantial (Harrison et al., 2008). They indicate a significant improvement in animal housing welfare, as animals create a natural bed in the plastic organic material, while separated sludge handling is very simple (Jelínek et al., 2006).

Increasing demands on the quality of animal products make it necessary to deal with improving of animal housing conditions, which include microclimate conditions of the environment, such as temperature and humidity (Balková and Pogran, 2009).

Organic bedding materials in a dry environment are characterized with high absorbability and low thermal conductivity. However, most organic bedding materials support bacterial growth (Russel et al., 2002). The monitoring of bacterial growth means depriving the bacterial substrate of the growth of some supportive factors: humidity, organic matter, and proper temperature and $\mathrm{pH}$. These properties also affect thermo-technical quantities (Chmúrny, 2003).

Thermo-technical conditions in a stable create a non-stationary process caused by climatic conditions and farm management (Pogran et al., 2000; Herbut and Angrecka, 2014).

Thermal comfort during lying is influenced by the structure of the bed characterised by thermal conductivity (reciprocally by thermal resistance), diffusivity and thermal effusivity.

Thermal conductivity $\lambda\left(\mathrm{Wm}^{-1} \mathrm{~K}^{-1}\right)$ is the ability of materials to conduct heat. Materials of low thermal conductivity (at least below $0.3 \mathrm{~W} \mathrm{~m}^{-1} \mathrm{~K}^{-1}$ ) are suitable as insulators for the animal lying area. However, it is a characteristic depending on the temperature and density of material. To avoid the heat loss from a building in winter periods, the material for the animal lying area should have heat conductivity as low as possible and the thermal resistance of floor structures should be as high as possible.

Most studies are based on measurements during steady climatic conditions, and there is little information 
about the change of thermo-technical characteristics in relation to changes in microclimate and animal welfare.

The aim of this work was the laboratory testing of thermo-technical properties of dry and wet separated manure solids in terms of their physical properties in different climatic conditions.

\section{Material and methods}

The samples of organic bedding from the Slovak University of Agriculture in Nitra dairy farm, which was obtained by separating the raw sludge of liquid manure, were used for this experiment. For the purpose of proper sanitation and reducing its humidity, the raw separated material was treated by drifting before using as bedding in the lying area.

By sampling we have focused on two characteristic bedding conditions dry condition and wet condition, while places directly contaminated by feces were not included in wet samples. 'Dry' samples of recycled manure solids (DRMS) were taken from the front of cubicles - below the head barrier, 'wet' samples of recycled manure solids (WRMS) were from the preparatory store, from fresh unused bedding. The samples from cubicles (each of $200 \mathrm{~g}$ ) were always taken from 10 cubicles in four rows. The samples from the preparatory store were collected at various depths of the heap with fresh unused separated sludge (each of $200 \mathrm{~g}$, too). From the first part of collected material of dry and wet samples, there were determined dry matter contents; the second part of the DRMS and WRMS samples was sealed and consequently used for testing of thermo-technical properties in laboratory.

Samples were pre-dried in a dryer HS 402 at a pre-drying temperature of $55 \pm 5{ }^{\circ} \mathrm{C}$. The drying of samples was performed in a drying equipment POL-Tote SLW 115 STD at $105^{\circ} \mathrm{C}$ until reaching the constant weight.

Thermo-technical properties were measured by two devices ISOMET (model 2104) using appropriate needle probes. Testing was performed in a chamber BINDER - KMF, with temperatures ranging from $0{ }^{\circ} \mathrm{C}$ to $+40{ }^{\circ} \mathrm{C}$. Sample temperature, air temperature, relative humidity, and air velocity were measured by three devices ALMEMO 2590 - 3S through external sensors.

Thermal resistance was calculated according to STN EN 730540 (2013).

\section{Results and discussion}

The average dry matter content was $60.65 \%$ for dry samples and $26.47 \%$ for wet samples.

Temperature changes did not significantly impact the moisture content of the sample; therefore, changes in humidity during the experiment were not taken into account. Table 1 shows the resulting average values of thermal conductivity $\lambda$ of DRMS and WRMS depending on temperature; $\theta_{a}$ is air temperature in the chamber; $\theta_{b, D R M s}$ is the temperature of dry samples, and $\theta_{\mathrm{b}}$, wrMs is the temperature of wet samples.

Standardised values of thermal conductivity coefficient $\lambda$ are presented at the material temperature of $10^{\circ} \mathrm{C}$. Fig. 1 shows that the thermal conductivity of dry samples $\lambda_{\text {DRMS }}$ and wet samples $\lambda_{\text {WRMS }}$ increases with increasing temperature, in accordance with the characteristics of Chmúrny (2003).

In the lowest temperature zone, the average values of measured thermal conductivity coefficient of the dry and wet RMS samples reached the values: $\lambda_{\text {DRMS, winter }}=0.155 \mathrm{~W} \mathrm{~m}^{-1} \mathrm{~K}^{-1}$ and $\lambda_{\text {WRMS, winter }}=0.233 \mathrm{~W} \mathrm{~m}^{-1} \mathrm{~K}^{-1}$. These values were considered as an input computing characteristic of winter dry or wet RMS, respectively. At the highest test temperature, we have observed an average value of thermal conductivity coefficient $\lambda_{\text {DRMS, summer }}=$ $0.164 \mathrm{~W} \mathrm{~m}^{-1} \mathrm{~K}^{-1}$, signifficantly different from wet bedding $\lambda_{\text {WRMS, summer }}=0.255$ $\mathrm{W} \mathrm{m}^{-1} \mathrm{~K}^{-1}$. We used them further as inputs for summer characteristics.

In normal bedding temperatures from $5{ }^{\circ} \mathrm{C}$ to $20{ }^{\circ} \mathrm{C}$, the thermal conductivity coefficient of dry RMS ranges on average from $\lambda_{\text {DRMS }}=0.151$ $\mathrm{W} \mathrm{m} \mathrm{m}^{-1}$ to $\lambda_{\text {DRMS }}=0.175 \mathrm{~W} \mathrm{~m}^{-1} \mathrm{~K}^{-1}$, which is similar to rubber (with its $\left.\lambda_{\text {rubber }}=0.16 \mathrm{~W} \mathrm{~m}^{-1} \mathrm{~K}^{-1}\right)$, and is better than that of aerated concrete $\left(\lambda_{\mathrm{ac}}=0.18\right.$ $\mathrm{W} \mathrm{m} \mathrm{m}^{-1}$ to $\lambda_{\mathrm{ac}}=0.23 \mathrm{~W} \mathrm{~m}^{-1} \mathrm{~K}^{-1}$ ), and slightly worse than chipboard $\left(\lambda_{\mathrm{ch}}=0.1\right.$ $\mathrm{W} \mathrm{m}^{-1} \mathrm{~K}^{-1}$ to $\lambda_{\mathrm{ch}}=0.12 \mathrm{~W} \mathrm{~m}^{-1} \mathrm{~K}^{-1}$ ).

Compared to dry samples, the thermal conductivity coefficient of WRMS is higher on average by $50.9 \%$ in winter and by $55.4 \%$ in summer. Its values range from $\lambda=0.228 \mathrm{~W} \mathrm{~m}^{-1} \mathrm{~K}^{-1}$ to $\lambda=0.272 \mathrm{~W} \mathrm{~m}^{-1} \mathrm{~K}^{-1}$. In ordinary bedding temperatures from $5{ }^{\circ} \mathrm{C}$ to $20{ }^{\circ} \mathrm{C}$, it is similar to wood or plasterboard (for both $\lambda=0.22 \mathrm{~W} \mathrm{~m}^{-1} \mathrm{~K}^{-1}$ ) and better than sand (from $\lambda=0.70 \mathrm{~W} \mathrm{~m}^{-1} \mathrm{~K}^{-1}$ ), slightly worse than sawdust (from $\lambda=0.12$ $\mathrm{W} \mathrm{m}{ }^{-1} \mathrm{~K}^{-1}$ to $\left.\lambda=0.16 \mathrm{~W} \mathrm{~m}^{-1} \mathrm{~K}^{-1}\right)$.

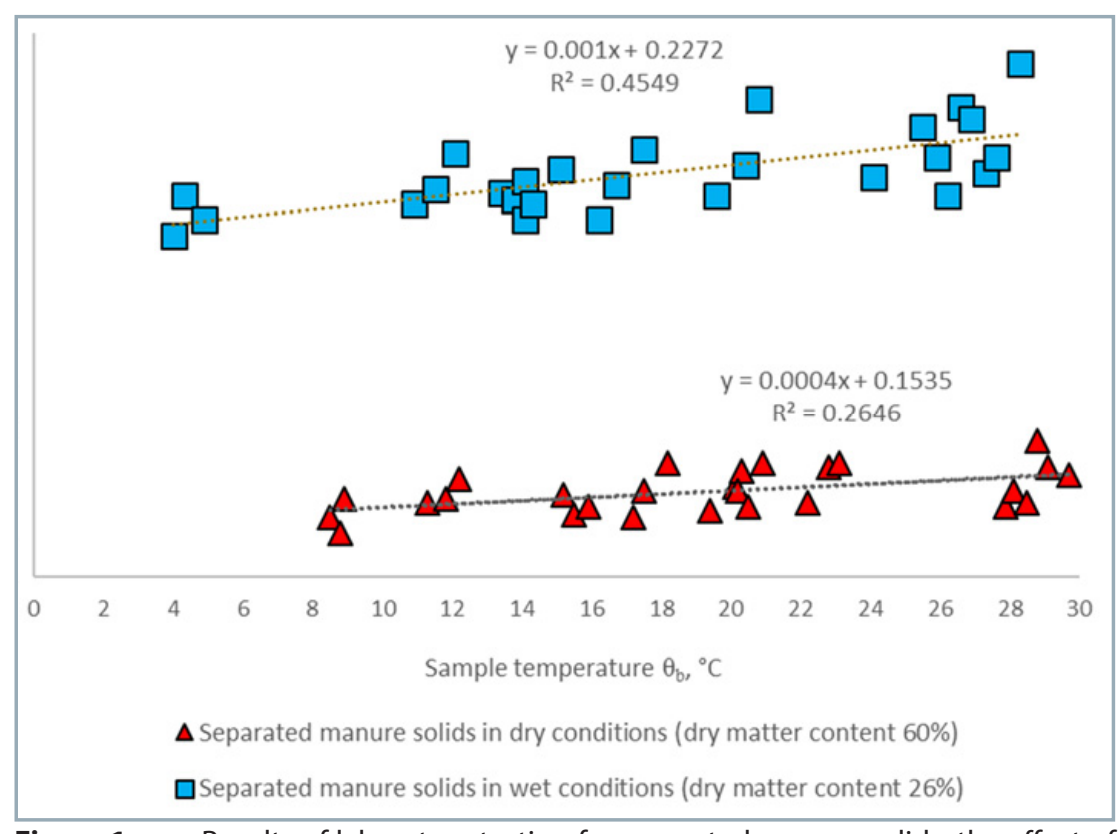

Figure 1 Results of laboratory testing for separated manure solids: the effect of sample temperature on the thermal conductivity coefficient of RMS; $\lambda_{\text {DRMS }}$ (triangle) and $\lambda_{\text {WRMS }}$ (square) 
Table 1 Results of laboratory tested thermo-technical properties of dry recycled manure solids (DRMS) and wet recycled manure solids (WRMS) samples of bedding

\begin{tabular}{|c|c|c|c|c|}
\hline $\begin{array}{l}\text { Air temperature } \\
\text { (in chamber) } \theta_{a} \text { in }{ }^{\circ} \mathrm{C}\end{array}$ & $\begin{array}{c}\text { Sample temperature } \\
\theta_{b, \text { DRMS }} \text { in } \theta \text { in }{ }^{\circ} \mathrm{C} \\
\end{array}$ & $\begin{array}{l}\text { Thermal conductivity } \\
\text { coefficient } \lambda_{\text {DRMS }} \text { in } \mathrm{W} \mathrm{m}^{-1} \mathrm{~K}^{-1}\end{array}$ & $\begin{array}{c}\text { Sample temperature } \\
\theta_{b, \text { wRMS }} \text { in }{ }^{\circ} \mathrm{C} \\
\end{array}$ & $\begin{array}{l}\text { Thermal conductivity } \\
\text { coefficient } \lambda_{\text {WRMs }} \text { in } \mathrm{W} \mathrm{m}^{-1} \mathrm{~K}^{-1}\end{array}$ \\
\hline 0 & 8.5 & 0.155 & 4 & 0.228 \\
\hline 0 & 8.8 & 0.151 & 4.3 & 0.238 \\
\hline 0 & 8.9 & 0.16 & 4.9 & 0.232 \\
\hline 5 & 11.3 & 0.159 & 10.9 & 0.236 \\
\hline 5 & 11.8 & 0.16 & 11.5 & 0.24 \\
\hline 5 & 12.2 & 0.165 & 12.1 & 0.249 \\
\hline 10 & 15.2 & 0.161 & 13.4 & 0.239 \\
\hline 10 & 15.5 & 0.156 & 13.8 & 0.237 \\
\hline 10 & 15.9 & 0.158 & 14.1 & 0.242 \\
\hline 15 & 17.2 & 0.155 & 14.1 & 0.232 \\
\hline 15 & 17.5 & 0.168 & 14.3 & 0.236 \\
\hline 15 & 18.2 & 0.169 & 15.1 & 0.245 \\
\hline 20 & 19.4 & 0.157 & 16.2 & 0.232 \\
\hline 20 & 20.1 & 0.163 & 16.7 & 0.241 \\
\hline 20 & 20.3 & 0.167 & 17.5 & 0.25 \\
\hline 25 & 20.2 & 0.162 & 19.6 & 0.238 \\
\hline 25 & 20.5 & 0.158 & 20.4 & 0.246 \\
\hline 25 & 20.9 & 0.169 & 20.8 & 0.263 \\
\hline 30 & 22.2 & 0.159 & 24.1 & 0.243 \\
\hline 30 & 22.8 & 0.168 & 25.5 & 0.256 \\
\hline 30 & 23.1 & 0.169 & 25.9 & 0.248 \\
\hline 35 & 27.9 & 0.158 & 26.2 & 0.238 \\
\hline 35 & 28.1 & 0.162 & 26.6 & 0.261 \\
\hline 35 & 28.8 & 0.175 & 26.9 & 0.258 \\
\hline 40 & 28.5 & 0.159 & 27.3 & 0.244 \\
\hline 40 & 29.1 & 0.168 & 27.6 & 0.248 \\
\hline 40 & 29.7 & 0.166 & 28.3 & 0.272 \\
\hline
\end{tabular}

For farmers, this means that from view of the tested thermo-technical properties, the dry bedding based on separated liquid manure is not worse than the rubber mattress, but it should often be cleaned and heap up with a drier one, also for sanitary reasons.

Each cleaning, levelling, removing and re-bedding of litter has a significant impact on the production of harmful gases and its optimization is important both for animals and for the environment (Karandušovská et al., 2013; Karandušovská et al., 2015). Recycled manure solids are almost exclusively used in cubicles, both on mattresses and as deep beds.

Figure 2 shows the results of calculations of three types of lying structures usually used in cubicle floor structures through the thermal resistance, which determines the ability of a building structure to ensure thermal protection. The higher the thickness of the structure (layer) and the lower the thermal conductivity coefficient of the structure (layer), the higher the thermal resistance. To calculate the thermal resistance (according to STN 730540), we have used the measured values of $\lambda_{\text {DRMS, winter }}=0.155 \mathrm{~W} \mathrm{~m}^{-1} \mathrm{~K}^{-1}$; $\lambda_{\text {WRMS, winter }}=0.233 \mathrm{~W} \mathrm{~m}^{-1} \mathrm{~K}^{-1} ; \lambda_{\text {DRMS, summer }}=0.164 \mathrm{~W} \mathrm{~m}^{-1} \mathrm{~K}^{-1}$ and $\lambda_{\text {WRMS summer }}=0.255 \mathrm{~W} \mathrm{~m}^{-1} \mathrm{~K}^{-1}$.

The thermal resistance of the lying floor structure should be as high as possible. If the farmer adds in winter for example $50 \mathrm{~mm}$ of this bedding, the prevention of heat leakage from the animal body lying on the floor (for any type of cow bed, excluding sandwich mattresses in which suitable input parameters are set) is doubled.

Prasad et al. (2013) tested differences in the thermal comfort of cows on concrete and rubber mattresses. From the study it becomes evident that the rubber floor had significantly higher temperature than the concrete floor 


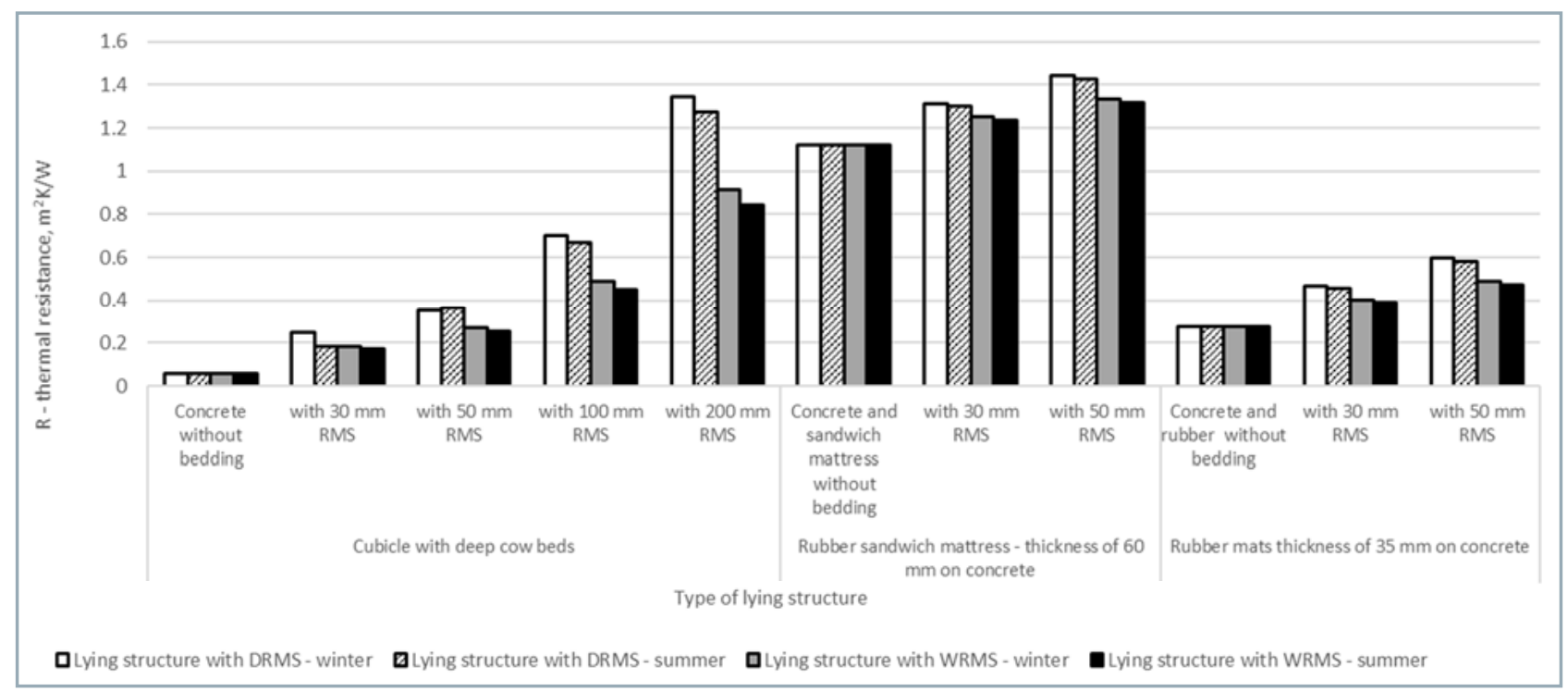

Figure 2 Results of calculated thermal resistance $R\left(\mathrm{~m}^{2} \mathrm{~K} \mathrm{~W}^{-1}\right)$ based on four characteristic boundary values of measured thermal conductivity for dry and wet bedding

during the day time, but they do not consider the spreading of further bedding.

The lying area for dairy cows has to be warm, clean, dry and soft. It was expected that the recycled manure solids will become moister when using in stables and that it will cause problems with its using for animals as bedding.

Recently, the testing of property changes in recycled bedding for dairy cows showed that after spreading the RMS - separated sludge slurry into cubicles in the stable with freestalls filled with drifted separated manure solids and those which use drum compost dried separated manure solids - there is a significant increase in dry matter during 2-8 days from starting dry matter of $27-38 \%$ to $65-67 \%$, which is positive in terms of hygiene and comfort (Husfeldt et al., 2012; Sorter et al., 2014; Lendelová et al., 2016). Recycled manure solids is a well formable bedding which improves the thermoinsulation quality of the lying area for dairy cows. On the contrary, the dry matter of straw in samples 1 collected after 2-3 hours of bedding acclimatisation in the stable was higher $(P<0.05)$, with a dry matter of $88.12 \%$ compared with $48.01 \%$ in samples 3 collected 2-3 hours before the new bedding was spread (Lendelová et al., 2016).

Drier bedding has better thermal insulation properties and the risk of bacteriological incidences is lower as decreasing the humidity of bedding material (Godden et al., 2008; Husfeldt et al., 2012a).

We have followed this positive information by determining the range of thermal conductivity depending on temperature for dry and wet bedding characteristics for winter and summer. According to Fig. 2, the best insulation properties in terms of thermal resistance are in the sandwich mattress with a $50 \mathrm{~mm}$ thick top layer of dry RMS, as well as deepened cubiles filled with a $200 \mathrm{~mm}$ layer of dry RMS in winter.

If cubicles are only as deepened beds based on concrete (without rubber mats or sandwich mattresses), it is needed to ensure that cubicles are fully filled with a plenty of dry RMS (and/or daily levelling of the lying area).
It is clear from Fig. 2 that if only $30 \mathrm{~mm}$ or $50 \mathrm{~mm}$ of dry RMS is put on the concrete surface, in terms of thermotechnical applicability it is more unsuitable than the case of only a $30 \mathrm{~mm}$ layer of wet RMS on $35 \mathrm{~mm}$ rubber mats.

A deepened cubicle with a dry straw of $200 \mathrm{~mm}$ thickness has $R=2.91 \mathrm{~m}^{2} \mathrm{~K} \mathrm{~W}^{-1}$ and it can prevent the heat loss from animal housing in winter reliably (Lendelová et al., 2009). However, if these cubicles are filled with a wet RMS of $200 \mathrm{~mm}$ thickness $\left(R=0.915 \mathrm{~m}^{2} \mathrm{~K} \mathrm{~W}^{-1}\right)$, we can get a very close result as compared to a wet straw of $200 \mathrm{~mm}$ thickness $\left(R=0.91 \mathrm{~m}^{2} \mathrm{~K} \mathrm{~W}^{-1}\right)$.

When comparing six bedding materials (chopped wheat straw, sand, pine shavings, chopped newspaper, chopped corn stalks, and recycled dairy manure solids), sand was the least absorbent, and recycled manure solids were the most absorbent on a weight for weight basis (Misselbrook and Powell, 2005).

In the final report from the Cornell University project 'Using Manure Solids as Bedding', it was also suggested that when adequately handled, RMS can offer economic advantages without affecting herd health (Harrison et al., 2008).

Carroll and Jasper (1978) reported that composting RMS effectively reduced coliform counts in compost piles. However, given the proper growth conditions of moisture and temperature when used as bedding in stalls, coliforms increased rapidly to large numbers in composted RMS due to replication of either bacteria surviving composting or those from external contamination (Carroll and Jasper, 1978). An important source of contamination for bedding in freestalls is manure on hooves and legs of cows that inoculate bedding material with fecal matter containing organisms. Environmental mastitis pathogens such as coliforms and environmental streptococci are shed in a significant amount by cows in their feces every day. These pathogens are normal inhabitants of the digestive tract and are excreted through the manure (Eghball et al., 1997).

Recycled manure solids have been used as a bedding material for dairy cows and the practice is becoming increasingly widespread, not only in Slovakia. 
There are significant uncertainties with respect to the associated risks to animal and human health from using RMS bedding. This in turn makes it difficult to establish whether the material can meet the requirements for safe use. The main risks to animal health that may alter as a result of a switch to the use of RMS as bedding are considered to be infectious diseases transmitted by pathogens present and persisting in the recycled bedding and effects of inhalation of bedding particulates had lower exposure since less dust is reported (Cole et al., 2016; Green et al., 2014).

A lot of farmers, not only in Slovakia, reported an improvement in the cleanliness of cows and a benefit to the condition of hocks (Husfeldt and Endres, 2012b). Their reports on changes in lying time were equally split between improvement and no change. Clinical mastitis incidence and somatic cell counts in most studies were qualitatively generally considered to be equal to or lower than before the change to the use of recycled manure solids as bedding. Incidents of mastitis or cell count problems were associated with fresh bedding material of lower dry matter content than usual (Green et al., 2014). There are some benefits as ease of slurry storage and handling, cow cleanliness, reduced emission, dust and ease of bedding handling (Cole and Hogan, 2016; Husfeldt et al., 2012; Karandušovska et al., 2012). The most common reasons for using RMS is cost, cow comfort and difficulties with the supply of alternative bedding materials.

It must be admitted that during the year the consistency of RMS changes in the farm and minor differences in physical characteristics can occur even in comparison with the results of various farms. This work provides input information on the effect of temperature differences on the thermal performance of bedding based on the separated liquid manure used at our university farm for 12 years. More extensive data set of tested samples of separated liquid manure for various technologies of preparation and use of bedding is subjected to a more extensive research. In terms of thermo-technical characteristics, the bedding from separated manure solids is mainly in dry condition an appropriate bedding material for dairy cows, very similar to straw.

\section{Conclusion}

During the laboratory testing of the thermo-technical properties of separated liquid manure for different climatic conditions, we have observed that in the range of air temperatures from $0{ }^{\circ} \mathrm{C}$ to $40^{\circ} \mathrm{C}$, the thermal conductivity of the recycled organic bedding is increasing with increasing samples temperature and humidity.

The highest thermal resistance values were reached in winter in dry bedding condition, with a $60 \%$ content of dry matter, when $R_{m}=1.44 \mathrm{~m}^{2} \mathrm{~K} \mathrm{~W}^{-1}$, or $R_{b}=1.347 \mathrm{~m}^{2} \mathrm{~K} \mathrm{~W}^{-1}$ (the case of sandwich mattresses with a $50 \mathrm{~mm}$ layer of dry recycled bedding, or in deep cow beds with a dry recycled bedding of $200 \mathrm{~mm}$ ).

Then, thermal conductivity coefficient was $\lambda=0.15 \mathrm{~W} \mathrm{mK}^{-1}$, and it increases with the increase in the moisture content of bedding material (up to dry matter $26 \%$ ), to $\lambda=0.27 \mathrm{~W} \mathrm{mK}^{-1}$. Thermal resistance drops to $R_{m}=1.335 \mathrm{~m}^{2} \mathrm{~K} \mathrm{~W}^{-1}$, or to $R_{b}=$ $0.915 \mathrm{~m}^{2} \mathrm{KW}^{-1}$.
In terms of the thermal protection of animals and buildings in winter, this is a $7.6 \%$ or $18.4 \%$ decrease in thermal protection compared to the use of dry bedding, but for the summer period, it allows a better release of heat from animals while lying on the floor. Attention must be paid to the sanitation and levelling of a bed. With a proper handling of the recycling organic bedding, it is possible to use its economic advantages.

\section{Acknowledgements}

Supported by the Ministry of Education of the Slovak Republic and the Slovak Academy of Sciences - VEGA, Grant No. $1 / 0575 / 14$.

\section{References}

BALKOVÁ, M. - POGRAN, Š. 2009. Assessment of microclimate parameters in the object for heifers. In Acta Technologica Agriculturae, vol. 12, 2009, no. 1, pp. 15-18.

BRESTENSKÝ, V. - BOTTO, L. 2010. Odstraňovanie a skladovanie hospodárskych hnojív. 1. ed., Nitra : Agrokomplex Nitra, 2010, 75 pp. CARROLL, E. J. - JASPER, D. E. 1978. Distribution of enterobacteriaceae in recycled manure bedding on California dairies. In Journal of Dairy Science, vol. 61, 1978, no. 10, pp. 1498-1508.

EGHBALL, B. - POWER, J. F. - GILLEY, J. E. - DORAN, J. W. 1997. Waste management: Nutrient, carbon, and mass loss during composting of beef cattle feedlot manure. In Journal of Environmental Quality, vol. 26, 1997, pp. 189-193.

CHMÚRNY, I. 2003. Tepelná ochrana budov. Bratislava : Jaga group, 2003. 214 pp. ISBN 80-88905-27-3.

COLE, K.J. - HOGAN, J. S. 2016. Short communication: Environmental mastitis pathogen counts in freestalls bedded with composted and fresh recycled manure solids. In Journal of Dairy Science, vol. 99, 2016, pp. 1501-1505.

GODDEN, S. - BEY, R. - LORCH, K. - FARNSWORTH, R. - RAPNICKI, P. 2008. Ability of organic and inorganic bedding materials to promote growth of environmental bacteria. In Journal of Dairy Science, vol. 91, 2008, no. 1, pp. 151-159.

GREEN, M. J. - LEACH, K. A. - BREEN, J. E. - OHNSTAD, I. - TUER, S. - ARCHER, S. C. - BRADLEY, A. J. 2014. Recycled manure solids as bedding for dairy cattle: A scoping study. In Cattle Practice, vol. 22, 2014, part 2, pp. 207-214.

HARRISON, E. - BONHOTAL, J. - SCHWARZ, M. 2008. Using Manure Solids as Bedding. Cornell Waste Management Institute. Ithaca, NY. (http://cwmi.css.cornell.edu/bedding.htm)

HERBUT, P. - ANGRECKA, S. 2014. Ammonia concentrations in a free-stall dairy barn. In Annals of Animal Science, vol. 14, 2014, no. 1, pp. 153-166.

HUSFELDT, A. W. - ENDRES, M. I. - SALFER, J. A. - JANNI, K. A. 2012a Management and characteristics of recycled manure solids used for bedding in Midwest freestall dairy herds. In Journal of Dairy Science, vol. 95, 2012, pp. 2195-2203.

HUSFELDT, A. W. - ENDRES, M. I. 2012b. Association between stall surface and some animal welfare measurements in freestall dairy herds using recycled manure solids for bedding. In Journal of Dairy Science, vol. 95, 2012, no. 10, pp. 5626-5634.

JELÍNEK, A. - KRAUS, R. - DĚDINA, M. 2006. Nová technologie zpracování kejdy $z$ chovu skotů jako plastického steliva pro zlepšení vztahu k životnímu prostředí a welfare chovaných zviřat. In Separovaná kejda jako plastické stelivo v chovech skotů. Praha : VUZT, 2006, pp. 8-13. ISBN 80-86884-14-7.

KARANDUŠOVSKÁ, I. - MIHINA, Š. - BOĎO, Š. 2012. Effect of differently designed systems of housing for dairy cows on 
ammonia and carbon dioxide concentration. In Acta Technologica Agriculturae, vol. 15, 2012, no. 4, pp. 106-109.

KARANDUŠOVSKÁ, I. - MIHINA, Š. - BOŠANSKÝ, M. 2015. Impact of construction and technological solution of dairy cows housing on production of ammonia and greenhouse gases in winter. In Research in Agricultural Engineering, vol. 61, 2015, special issue, pp. 13-20.

KARANDUŠOVSKÁ, I. - MIHINA, Š. - LENDELOVÁ, J. - BOĎO, Š. PÁLEŠ, D. - PITERKA, P. - BOŠANSKÝ, M. 2013. Investigating the impact of manure removal frequency on the amount of produced pollutants in cattle housing. In Journal of Central European Agriculture, vol. 14, 2013, no. 4, pp. 1262-1269.

LENDELOVÁ, J. - ČIČO, P. - ŽITŇÁK, M. - MIHINA, Š. - POGRAN, Š. 2015. Podlaha ležísk pre dojnice $z$ recyklovaného biologického odpadu : utility model no. 7222 : date of entry and public availability of the utility model 24 June 2015. Banská Bystrica: Industrial Property Office of the Slovak Republic, 2015, 5 pp.

LENDELOVÁ, J. - MIHINA, Š. - POGRAN, Š. 2009. Organic bedding materials and their thermo-technical properties in different climate conditions. In Book of Abstracts of the $60^{\text {th }}$ Annual Meeting of the European Association for Animal Production: Book of abtracts No. 15 (2009), Barcelona, Spain, 24-27 August 2009. Wageningen: Wageningen Academic Publishers, 2009. ISBN 978-90-8686-121-7. LENDELOVÁ, J. - ŽITŇÁK, M. - BOŠANSKÝ, M. - ŠIMKO, M. - PITERKA, P. 2016. Testing of property changes in recycled bedding for dairy cows. In Research in Agricultural Engineering, vol. 62, 2016, special issue, pp. S44-S52.
MISSELBROOK, T. H. - POWELL, J. M. 2005. Influence of bedding material on ammonia emissions from cattle excreta. In Journal of Dairy Science, vol. 88, no. 12, December 2005, pp. 4304-4312.

POGRAN, Š. - LENDELOVÁ, J. - VERNAREC, J. 2000. Analýza vplyvu vlhkosti na stavebné materiály $\mathrm{v}$ ustajňovacích objektoch. In Construmat 2000. Nitra : SPU, 2000, pp. 154-158.

PRASAD, A. - VISHNU SAVANTH, V. - ANIL, K. S. - SASEENDRAN P. C. 2013. Impact of rubber mat flooring on the thermal comfort of dairy cattle in hot humid regions. In Tamilnadu J. Veterinary \& Animal Sciences, vol. 9, 2013, no. 4, pp. 272-278.

RUSSEL, B. F. - RENAU, J. K. - FARNSWORTH, R. J. 2002. The role of bedding management in udder health. In Proceedings of the $41^{\text {st }}$ Annual Meeting of the National Mastitis Council, pp. 45-55.

Slovak technical standard STN 73 0540. 2012. Thermal Protection of Buildings. Thermal Performance of Buildings and Components.

SORTER, D. E. - KESTER, H. J. - HOGAN, J. S. 2014. Short communication: Bacterial counts in recycled manure solids bedding replaced daily or deep packed in freestalls. In Journal of Dairy Science, vol. 97, 2014, no. 5, pp. 2965-2968. 